\title{
HUBUNGAN FREKUENSI LAMA MENJALANKAN HD DENGAN KADAR TROMBOSIT PADA PASIEN CKD DI RSPBA BANDAR LAMPUNG
}

\author{
Nurul Jannah¹, Hetti Rusmini², Ratna Purwaningrum³, Rina Kriswiastiny ${ }^{4}$ \\ ${ }^{1}$ Program Studi Kedokteran Fakultas Kedokteran Universitas Malahayati \\ ${ }^{2}$ Departemen Farmakologi Fakultas Kedokteran Universitas Malahayati \\ ${ }^{3}$ Departemen Histologi Fakultas Kedokteran Universitas Malahayati \\ ${ }^{4}$ Departemen Penyakit Dalam Rumah Sakit Pertamina Bintang Amin
}

[email korespondensi: Jannahnurul678@gmail.com]

\begin{abstract}
Long Frequency Relationship with Thrombocyte Levels in CKD Patients at RSPBA Bandar Lampung. Chronic Chronic Kidney Disease (CKD) is a very serious problem, where there is kidney damage that occurs for more than 3 months, the usual therapy for CKD patients is hemodialysis which is used to take toxic nitrogen substances from the blood, these actions have side effects on the physical and psychological conditions of people with CKD. Thrombocyte have an important role in protecting the endothelial integrity of blood vessels in the hemostatic process if there is damage to the blood vessels. Count examination results are influenced by temperature and time since specimen collection. In laboratory examination, abnormalities of the platelets may occur, namely thrombocytopenia and thrombocytosis. This study is a retrospective observational analytic study with a cross sectional design. The sampling technique was total sampling, with 76 samples used. Based on the length of HD treatment on platelet levels obtained ( $p$-value $=0.294)$, while the length of time of HD implementation on platelet levels ( $p$-value 0.014 ). There is no significant long -term relationship of HD treatment with platelet count in CKD patients, and there is a significant long term relationship of $\mathrm{HD}$ process with platelet count in CKD patients in RSPBA Bandar Lampung Year 2019 - 2020.
\end{abstract}

Keywords: CKD, HD, Thrombocyte Count

\begin{abstract}
Abstrak: Hubungan Frekuensi Lama Menjalankan HD dengan Kadar Trombosit pada Pasien CKD di Rspba Bandar Lampung. Chronic Kidney Disease (CKD) merupakan masalah yang sangat serius, dimana terjadi kerusakan ginjal yang terjadi selama lebih dari 3 bulan, terapi yang biasa dilakukan untuk pasien ckd adalah dengan melakukan hemodialisa dimana digunakan untuk mengambil zat - zat nitrogen yang bersifat toksik dari dalam darah, tindakan tersebut mempunyai efek samping pada kondisi fisik serta psikologis penderita CKD. Trombosit memiliki peran penting yaitu melindungi integritas endotel pembuluh darah dalam proses hemostasis apabila terjadi kerusakan pada dinding pembuluh darah. Hasil pemeriksaan hitung trombosit dipengaruhi oleh suhu dan waktu sejak pengumpulan spesimen. Hasil pemeriksaan hitung trombosit dipengaruhi oleh suhu dan waktu sejak pengumpulan spesimen. Pada pemeriksaan laboratorium bisa terjadi kelainan pada trombosit yaitu trombositopenia dan trombositosis. Penelitian ini bersifat analitik retrospektif dengan desain cross sectional. Teknik pengambilan sampel secara total sampling, dengan sampel yang dipakai sebanyak 76. Berdasarkan lama menjalankan perawatan HD terhadap kadar trombosit diperoleh $(p$-value $=0,294)$, sedangkan lama waktu pelaksanaan HD terhadap kadar trombosit $(p$-value 0,014$)$. Tidak terdapat hubungan yang signifikan lama menjalankan perawatan HD dengan kadar trombosit pada pasien CKD, dan terdapat hubungan yang signifikan lama proses HD dengan kadar trombosit pada pasien CKD di RSPBA Bandar Lampung Tahun 2019 - 2020.
\end{abstract}

Kata Kunci : CKD, HD, Kadar Trombosit 


\section{PENDAHULUAN}

Chronic Kidney Disease (CKD) yaitu kerusakan ginjal yang terjadi selama lebih dari 3 bulan, berdasarkan kelainan patologis atau petanda kerusakan ginjal seperti proteinuria. Berbagai faktor yang mempengaruhi kecepatan kerusakan serta penurunan fungsi ginjal dapat berasal dari genetik, perilaku, lingkungan maupun proses degeneratif (Fadhilah, 2014).

Hemodialisa merupakan tindakan yang digunakan untuk mengambil zatzat nitrogen yang bersifat toksik dari dalam darah dan mengeluarkan air yang berlebih. Dosis hemodialisis yang diberikan umumnya biasa 2 kali dalam seminggu dengan setiap hemodialisa 5 jam atau sebanyak 3 kali seminggu dengan setiap hemodialisa selama 4 jam. Lamanya hemodialisa berkaitan erat dengan efisiensi dan adekuasi hemodialisa, sehingga pada lama hemodialisa juga dipengaruhi oleh tingkat uremia akibat progresivitas perburukan fungsi ginjalnya dan faktorfaktor komorbiditasnya, serta kecepatan aliran darah dan kecepatan aliran dialisat (Maqrifah dkk, 2020).

Menurut World Health

Organization (WHO) pertumbuhan jumlah penderita gagal ginjal kronik di dunia pada tahun 2013 meningkat sebesar $50 \%$ dari tahun sebelumnya dan di Amerika angka kejadian gagal ginjal kronik meningkat sebesar $50 \%$ pada tahun 2014 dan setiap tahun 200.000 orang Amerika menjalani hemodialisis (Widyastuti, 2014).

Pasien yang menjalani hemodialisa kadar trombosit biasanya dilihat dari pre dan post saat melakukan hemodialisa, seperti penelitian yang dilakukan oleh Sri ujiani, Maria Tutun dan Tiatira Magdalena Rentha Hasibuan di RSUD dr. H. Abdul Moeloek Provinsi Lampung tahun 2017 nilai rata-rata jumlah trombosit pre hemodialisa didapatkan sebesar 462,100/mm3, dan nilai rata-rata jumlah trombosit post hemodialisa didapatkan sebesar $277,666 / \mathrm{mm} 3$. Jumlah trombosit pre hemodialisa dengan kategori diatas nilai normal sebanyak 16 pasien (53.3\%), dan jumlah trombosit post hemodialisa dengan kategori sesuai dengan nilai normal sebanyak 22 pasien (73.3\%). Dari data penelitian tersebut menunjukkan 4 pasien mengalami kenaikan nilai jumlah trombosit setelah menjalani proses hemodialisa (Ujiani, 2018).

Berdasarkan hasil pre survey yang dilakukan di RSPBA Bandar Lampung terdapat 76 pasien yang melakukan hemodialisa pada sepanjang tahun 2019 - 2020 dengan kriteria pasien baru dan pasien lama.

\section{METODE}

Jenis penelitian yang digunakan adalah analitik retrospektif dengan menggunakan pendekatan cross sectional. Populasi dalam penelitian ini sebanyak 76 pasien yang melakukan HD (Hemodialisa) di Rumah Sakit Pertamina Bintang Amin Bandar Lampung Tahun 2019 - 2020. Responden yang memenuhi kriteria inklusi sebanyak 76 pasien. Pengambilan data dilakukan dengan mengambil data Rekam Medik pasien. Analisis yang digunakan untuk penelitian ini adalah menggunakan metode uji chi square.

HASIL

1. Analisis Univariat

Tabel. 1. Distribusi Frekuensi Umur Responden

\begin{tabular}{ccc}
\hline Usia & Frekuensi & Persentase \\
\hline 26-35 Tahun & 2 & 3 \\
36-35 Tahun & 7 & 9 \\
46-55 Tahun & 27 & 36 \\
56-65 ahun & 28 & 37 \\
>65 tAHUN & 12 & 16 \\
Total & 76 & 100 \\
\hline
\end{tabular}


Berdasarkan tabel 1 diatas menunjukkan distribusi paling banyak adalah lansia akhir yaitu sebanyak 28 responden $(37 \%)$, selanjutnya Iansia awal sebanyak 27 responden (37\%) dan distribusi terendah adalah dewasa awal yaitu sebanyak 2 responden (3\%).

Tabel. 2. Distribusi Frekuensi Jenis Kelamin Responden

\begin{tabular}{|c|c|c|c|}
\hline Jenis Kelamin & rekuensi & Persentase & \\
\hline Perempuan & 32 & 42 & \\
\hline Laki - Laki & 44 & 58 & \\
\hline Total & 76 & 100 & \\
\hline $\begin{array}{l}\text { Berdasarkan tabel } 2 \text { menunjukkan } \\
\text { distribusi paling banyak adalah laki-laki } \\
\text { yaitu sebanyak } 44 \text { responden }(58 \%)\end{array}$ & $\begin{array}{l}\text { dan perempuan } \\
\text { responden }(42 \%) \text {. }\end{array}$ & sebanyak & 32 \\
\hline Lama Hemodialisa & rekuensi & Persentase & \\
\hline $\begin{array}{l}<6 \text { Bulan } \\
>6 \text { Bulan }\end{array}$ & $\begin{array}{l}16 \\
60\end{array}$ & $\begin{array}{l}13 \\
87\end{array}$ & \\
\hline Total & 76 & 100 & \\
\hline
\end{tabular}

Berdasarkan tabel 3 diatas, lama hemodialisa yang dialami oleh responden menunjukkan sebagian besar adalah lebih dari 6 bulan yaitu sebanyak
60 responden (87\%) dan sisanya kurang dari 6 bulan sebanyak 16 responden (13\%).

Tabel. 4. Distribusi Frekuensi Lama Waktu Pelaksanaan Hemodialisa

\begin{tabular}{ccc} 
Lama proses Hemodialisa & Frekuensi & Persentase \\
\hline $2-3$ jam & 4 & 5 \\
$4-5$ jam & 72 & 95 \\
\hline Total & 76 & 100 \\
\hline
\end{tabular}

Berdasarkan tabel 4, lama proses hemodialisa yang dialami oleh responden menunjukkan sebagian besar adalah 4 - 5 jam yaitu sebanyak 72 responden (95\%) dan sisanya 2 - 3 jam sebanyak 4 responden ( $5 \%)$.

Tabel. 5. Distribusi Frekuensi Kadar Trombosit

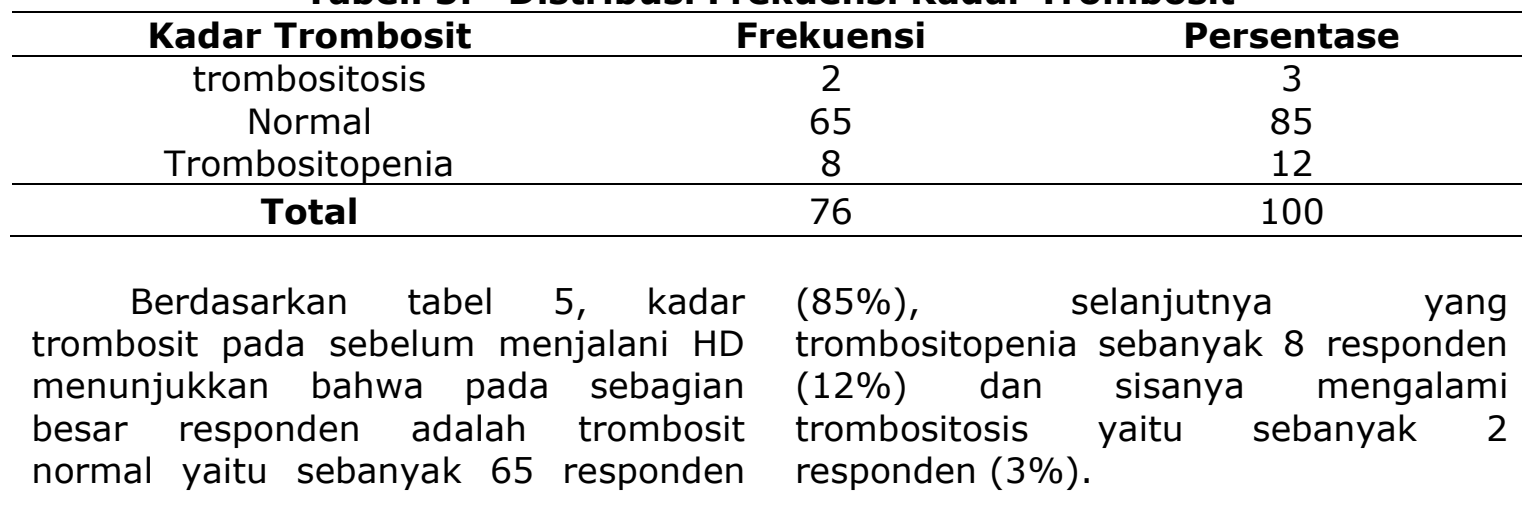




\section{Analisis Bivariat}

Tabel . 6 Hasil Uji Chi square Hubungan Kadar Trombosit dengan Lama Pengobatan Hemodialisa

\begin{tabular}{|c|c|c|c|c|c|c|c|c|}
\hline \multirow{3}{*}{$\begin{array}{c}\text { Lama } \\
\text { pengobatan } \\
\text { HD }\end{array}$} & \multicolumn{8}{|c|}{ Kadar Trombosit } \\
\hline & \multicolumn{2}{|c|}{ Trombositosis } & \multicolumn{2}{|c|}{ Normal } & \multicolumn{2}{|c|}{ Trombositopenia } & \multicolumn{2}{|c|}{ Jumlah } \\
\hline & 1 & 10 & 8 & 80 & 1 & 10 & 10 & 100 \\
\hline$\geq 6$ bulan & 1 & 2 & 57 & 86 & 7 & 12 & 66 & 100 \\
\hline Total & 9 & 12 & 65 & 85 & 2 & 3 & 76 & 100 \\
\hline$p$-value & & & & & 0,294 & & & \\
\hline
\end{tabular}

Hasil uji chi square hubungan lama menjalankan perawatan dengan HD terhadap kadar trombosit diperoleh nilai signifikansi uji ( $p$-value) sebesar 0,294. Karena nilai signifikansi uji $(p=$ value $)$ lebih besar dari $0,05(0,294>0,05)$ maka keputusan uji adalah $\mathrm{H}_{0}$ diterima.
Berdasarkan keputusan uji maka disimpulkan bahwa tidak terdapat hubungan yang signifikan lama menjalankan perawatan HD dengan kadar trombosit pada pasien CKD di RSPBA Bandar Lampung Tahun 2019 2020.

\section{Tabel 7. Hasil Uji Chi square Hubungan Kadar Trombosit dengan Lama} Waktu Pelaksanaan Hemodialisa

\begin{tabular}{|c|c|c|c|c|c|c|c|c|}
\hline \multirow{2}{*}{$\begin{array}{c}\text { Lama waktu } \\
\text { pelaksanaan } \\
\text { HD }\end{array}$} & \multicolumn{8}{|c|}{ Kadar Trombosit } \\
\hline & \multicolumn{2}{|c|}{ Trombositosis } & \multicolumn{2}{|c|}{ Normal } & \multicolumn{2}{|c|}{ Trombositopenia } & \multicolumn{2}{|c|}{ Jumlah } \\
\hline 2-3 jam & 0 & 0 & 5 & 75 & 1 & 25 & 4 & 100 \\
\hline 4-5 jam & 9 & 13 & 65 & 86 & 1 & 1 & 72 & 100 \\
\hline Total & 9 & 12 & 65 & 85 & 2 & 3 & 76 & 100 \\
\hline$p$-value & \multicolumn{8}{|c|}{$=0,014$} \\
\hline
\end{tabular}

Hasil uji chi square hubungan lama proses HD terhadap kadar trombosit diperoleh nilai signifikansi uji ( $p$-value) sebesar 0,014 . Karena nilai signifikansi uji $(p=$ value $)$ lebih kecil dari 0,05 $(0,014>0,05)$ maka keputusan uji adalah $\mathrm{H}_{0}$ ditolak. Berdasarkan keputusan uji maka disimpulkan bahwa terdapat hubungan yang signifikan lama proses HD dengan kadar trombosit pada pasien CKD di RSPBA Bandar Lampung Tahun 2019 - 2020.

\section{PEMBAHASAN}

\section{Karakteristik Umur Responden}

Karakteristik usia responden pada penelitian ini menunjukkan sebagian besar merupakan lansia akhir (56 - 65 tahun) yaitu 39\% dari total sampel. Hasil ini sesuai dengan hasil penelitian sebelumnya yaitu Prasetyo, dkk (2018) yang menunjukkan bahwa rata-rata usia pasien gagal ginjal kronik yang menjalani hemodialisa di Cilacap rata-rata berusia 49,5 tahun. Demikian pula dengan penelitian Siregar dan Muhammad (2019) yang menunjukkan bahwa rata-rata usia pasien penyakit ginjal kronik yang dirawat di RS Hasan Sadikin Bandung tahun 2018 rata-rata berusia 45 tahun.

Setelah usia 30 tahun, ginjal akan mengalami atrofi dan ketebalan kortek ginjal akan berkurang sekitar $20 \%$ setiap dekade. Perubahan lain yang akan terjadi seiring dengan bertambahnya usia berupa penebalan membran basal glomerulus, ekspansi mesangium glomerular dan terjadinya deposit protein matriks ekstraselular sehingga menyebabkan glomerulosklerosis (Levey et al, 2005). 


\section{Karakteristik Jenis Kelamin Responden}

Karakteristik jenis kelamin responden penelitian ini sebagian besar adalah adalah laki-laki yaitu sebanyak $55 \%$ dari total populasi. Hal ini sesuai dengan hasil penelitian Prasetyo, dkk (2018) yang menunjukkan bahwa $58 \%$ pasien gagal ginjal adalah laki-laki. Pada penelitian ini didapatkan laki-laki lebih banyak yang mengalami penyakit ginjal kronis.

Hasil temuan ini bertolak belakang dengan studi oleh Hill et al (2016) dalam studi dengan metode sistematik review memperlihatkan wanita lebih mendominasi dibanding laki-laki. Meskipun demikian, penelitian penyakit kronis ginjal yang melibatkan pasien dengan gangguan urologi memperlihatkan laki-laki lebih mendominasi dibanding perempuan.

\section{Gambaran Lama Pengobatan Hemodialisa \\ Distribusi frekuensi lama} menjalankan perawatan hemodialisa yang dialami oleh responden menunjukkan sebagian besar adalah lebih dari 6 bulan (87\%) dan sisanya kurang dari 6 bulan (13\%). Berdasarkan hasil penelitian, maka nampak bahwa sebagian besar responden telah menjalani hemodialisa dalam jangka waktu yang cukup lama.

Gagal ginjal merupakan kondisi yang mengakibatkan ginjal kehilangan kemampuannya untuk mempertahankan volume dan komposisi cairan tubuh dalam keadaan asupan makan normal. gagal ginjal kronik berlangsung perlahan-lahan selama tiga bulan atau lebih dan dapat menyebabkan gagal ginjal yang permanen. Sampai saat ini ada tiga jenis terapi yang tersedia yaitu hemodialisis, peritoneal dialisis dan transplantasi ginjal (Baradero, 2009; PERNEFRI, 2012).

\section{Gambaran Lama Pelaksanaan Hemodialisa}

Distribusi frekuensi lama proses hemodialisis yang dialami oleh responden menunjukkan sebagian besar 4 - 5 jam yaitu sebanyak 95\%. Penyakit ginjal kronik (PGK) adalah suatu proses patofisiologis dengan etiologi yang beragam, mengakibatkan penurunan fungsi ginjal yang progresif dan pada umumnya berakhir dengan gagal ginjal. Penurunan fungsi ginjal pada suatu derajat akan memerlukan terapi pengganti ginjal yang tetap berupa dialisis atau transplantasi ginjal. Salah satu cara penanganan PGK adalah terapi hemodialisis. Hemodialisis sebagai terapi pengganti ginjal telah menyelamatkan nyawa jutaan individu. Terapi hemodialisis merupakan terapi yang bertujuan menghilangkan gejala uremia, memperbaiki keseimbangan elektrolit, asam basa dan cairan menggunakan mesin ginjal buatan yang terdiri dari membrane semi permeable (Damayanti dkk, 2019).

\section{Gambaran Kadar Trombosit}

Gambaran kadar trombosit pada sebelum menjalani HD menunjukkan bahwa pada sebagian besar responden adalah normal (85\%) selanjutnya yang trombositopenia sebanyak (12\%) dan sisanya mengalami trombositosis yaitu sebanyak (3\%). Penelitian menunjukkan bahwa kadar trombosit responden adalah normal (150.000 - $400.000 \mu \mathrm{l})$. $\mathrm{Hal}$ ini sebagaimana dikemukakan oleh Kaparang, dkk (2013) bahwa pasien CKD bila dilakukan pengontrolan yang ketat terhadap pemberian heparin tidak akan memberikan efek samping yang banyak terhadap nilai trombosit. Pada pasien yang melakukan hemodialisa kadar trombosit yang menurun faktor yang mempengaruhi yaitu pemberian heparin dan pemasangan akses selang mesin hemodialisa yang tidak sesuai di pembuluh darah pasien, sehingga menyebabkan proses pencucian darah tidak lancar karena adanya kontak udara. Sedangkan pada trombositosis faktor yang mempengaruhi yaitu pada saat proses penarikan cairan dari dalam tubuh pasien oleh mesin hemodialisa (proses difusi) yang menyebabkan cairan dalam tubuh pasien menjadi lebih pekat (Ujiani dkk, 2018). 


\section{Hubungan Kadar Trombosit dengan Lama Pengobatan HD}

Hasil uji chi square hubungan lama menjalankan perawatan dengan HD terhadap kadar trombosit diperoleh nilai signifikansi uji ( $p$-value) sebesar 0,294 . Karena nilai signifikansi uji $(p=$ value) lebih besar dari 0,05 (0,294 $>0,05)$ maka keputusan uji adalah $\mathrm{H}_{0}$ diterima. Berdasarkan keputusan uji maka disimpulkan bahwa tidak terdapat hubungan yang signifikan lama menjalankan perawatan HD dengan kadar trombosit pada pasien CKD di RSPBA Bandar Lampung Tahun 20192020. Hasil penelitian ini didukung oleh Kandacong (2017) yang menyimpulkan bahwa tidak ada hubungan antara frekuensi hemodialisa dengan jumlah hitung trombosit pada pasien ginjal kronik.

Namun hasil penelitian ini berbeda dengan hasil penelitian Damayanti, dkk (2019) yang menyimpulkan bahwa tidak terdapat perbedaan nilai Neutrofil Limfosit Rasio (NLR) pasien PGK sebelum dan sesudah hemodialisa dan terdapat perbedaan nilai Trombosit Limfosit Rasio (TLR) pasien PGK sebelum dan sesudah hemodialisa (Damayanti dkk, 2019).

Pada proses dialisis terjadi aliran darah di luar tubuh. Pada keadaan ini akan terjadi aktivasi sistem koagulasi darah dengan akibat timbulnya bekuan darah. Karena itu pada dialisis diperlukan pemberian heparin selama dialisis berlangsung. Ada tiga teknik pemberian heparin yaitu teknik heparin rutin heparin minimal, dan bebas heparin. Pada teknik heparin rutin, teknik yang paling sering digunakan sehari-hari, heparin diberikan dengan cara bolus diikuti dengan continuus infusion. Pengontrolan pemberian heparin yang ketat dapat mengurangi efek samping hemodialisis (Suwitra, 2009).

\section{Hubungan Kadar trombosit dengan Lama Waktu Pelaksanaan HD}

Hasil uji chi square hubungan lama proses HD terhadap kadar trombosit diperoleh nilai signifikansi uji ( $p$-value) sebesar 0,014. Karena nilai signifikansi uji ( $p=$ value) lebih kecil dari $0,05(0,014>0,05)$ maka keputusan uji adalah $\mathrm{H}_{0}$ ditolak. Berdasarkan keputusan uji maka disimpulkan bahwa terdapat hubungan yang signifikan lama proses HD dengan kadar trombosit pada pasien CKD di RSPBA Bandar Lampung Tahun 2019 - 2020.

Penelitian menunjukkan bahwa terdapat hubungan lama proses HD dengan kadar trombosit. Hal tersebut sesuai dengan tujuan pelaksanaan hemodialisa yaitu untuk mengambil zat - zat nitrogen yang toksik dari dalam darah dan mengeluarkan air yang berlebihan. Ada tiga prinsip yang mendasari kerja hemodialisis yaitu: difusi, osmosis, dan ultrafiltrasi. Kelebihan air dibuang dengan menciptakan tekanan hidrostatik darah lebih tinggi yang bergerak dalam dialiser (ginjal buatan), dibanding dalam dialisat (cairan dialisis), yang mengalir dengan arah berlawanan.

\section{KESIMPULAN}

Berdasarkan hasil penelitian dan pembahasan, maka peneliti dapat menyimpulkan bahwa prevalensi pasien HD di RSPBA Bandar Lampung Tahun 2019 - 2020 sebagian besar memiliki nilai trombosit normal (85\%). Lama menjalankan perawatan hemodialisa pada pasien CKD di RSPBA Bandar Lampung Tahun 2019 - 2020 sebagian besar adalah lebih dari 6 bulan (87\%). Lama waktu hemodialisis pada pasien CKD di RSPBA Bandar Lampung Tahun 2019 - 2020 sebagian besar adalah 4 5 jam (95\%).

Tidak terdapat hubungan yang signifikan lama menjalankan perawatan HD dengan kadar trombosit pada pasien CKD di RSPBA Bandar Lampung Tahun 2019 - 2020 (95\%). Terdapat hubungan yang signifikan lama proses HD dengan kadar trombosit pada pasien CKD di RSPBA Bandar Lampung Tahun 2019 - $2020(0,014)$

\section{SARAN}

Hasil penelitian ini menunjukkan bahwa tidak terdapat hubungan yang signifikan lama hemodialisis dengan kadar trombosit pasien. Hal ini 
menunjukkan bahwa pelaksanaan hemodialisis yang dilaksanakan oleh rumah sakit telah terlaksana dengan baik, sehingga pihak rumah sakit diharapkan senantiasa berusaha untuk mempertahankan bahkan meningkatkan keberhasilan ini.

Peneliti selanjutnya diharapkan menggunakan metode penelitian yang lebih baik misalnya menggunakan case control sehingga perjalanan penyakit pasien lebih jelas diketahui, sehingga adanya factor-faktor lain yang berhubungan dengan kadar trombosit pasien selama sakit dan hemodialisis dapat diketahui.

\section{UCAPAN TERIMAKASIH}

Ucapan terimakasih ini disampaikan kepada Orang tua serta teman -teman dan Universitas Malahayati yang telah mendukung pelaksanaan penelitian.

\section{DAFTAR PUSTAKA}

Baradero, M., Esty, W. Mary, W.D., Monica, E., dan Yakobus, S. (2009). Seri Asuhan Keperawatan: Klien Gangguan Ginjal. Jakarta: EGC

Damayanti, A., Elisabeth, L, S. S., Stefany, A. W. (2019). Perbedaan Neutrofil Limfosit Rasio dan Trombosit Limfosit Rasio Pre dan Post Hemodialisis Pada Pasien Penyakit Ginjal Kronik di RSUD Prof. DR. W. Z. JOHANNES KUPANG. Cendana Medical Journal 17(2).

Fadhilah, A. Z. (2014). Chronic Kidney Disease Stage V. Jurnal Kesehatan dan Agromedicine 1(2).

Hill, N. R., Fatoba, S. T., Oke, J. L., Hirst, J. A., O'Callaghan, C. A., Lasserson, D. S., \& Hobbs, F.R. (2016). Global Prevalence of Chronic Kidney Disease $A$ Systematic Review And MetaAnalysis. United Kingdom: Plos One.

Kandacong, A, C. (2017). Jumlah Trombosit Pre dan Post Hemodialisis (HD) Pada Pasien Penyakit Gagal Ginjal Kronik
(PGK) di Rumah Sakit Perguruan Tinggi Negeri (RSPTN) Universitas Hasanuddin. [Skripsi]. Makassar: Universitas Hasanuddin.

Kaparang, S., Emma, S, M., Linda, R. (2013). Nilai Trombosit Pada Pasien Penyakit Ginjal Kronik Yang Menjalani Hemodialisis Di Unit Hemodialisis Bagian/SMF Ilmu Penyakit dalam FK Unsrat BLU RSUP PROF. DR. R. D. Kandou Manado. Jurnal ebiomedik (Ebm) 1(1): 95 100.

Levey, A, S., Kai-Uwe, E. Yusuke, T., Adeera, L., Josef, C., Jerome, R., et al. (2005). Definition and Classification of Chronic Kidney Disease: A Position Statement from Kidney Disease: Improving Global Outcomes (KDIGO). Kidney International. 67(6): 2089-2100.

Maqrifah, A. N., Retno, D.N., dan Dewi, M. (2020). Hubungan Lama Menjalani Hemodialisis Dan Kepatuhan Diet Dengan Kadar Hemoglobin Pasien Hemodialisis Di RSUD Pandan Arang Boyolali. PROFESI (Profesional Islam) Media Publikasi Penelitian 17(2).

PERNEFRI. (2012). Annual Report of Indonesia Renal Registry. https://www. penefriinasn.org/l aporan/5th\%20annual\%20repo rt\%20\%IRR\%202012.

Prasetyo, A., Suko, P., Neni, H. (2018). Karakteristik Pasien Gagal Ginjal yang Menjalani Terapi Hemodialisa di RSUD Cilacap. Prosiding seminar Nasional dan Diseminasi Penelitian Kesehatan STIKes Bakti Tunas Husada Tasikmalaya, 21 April 2018 ISBN : 978-602-72636-35.

Siregar, S. dan Muhammad, I. K. (2019). Karakteristik Pasien Penyakit Ginjal Kronis yang di Rawat di Rumah Sakit Hasan Sadikin Bandung Tahun 2018. 
Jurnal Pengabdian kepada

Masyarakat 4(4): 82-85.

Suwitra, K. (2014). Penyakit Ginjal Kronik Dalam I Setiati S, Alwi I, Sudoyo AW, SImadibrata M, Setyohadi B, penyunting. Buku Ajar Ilmu Penyakit Dalam. Jakarta: Pusat Penerbitan Departemen Ilmu Penyakit Dalam FKUI. hlm. 2161-2167.

Ujiani, S., Maria, T., dan Tiatira, M.R.H. (2018). Perbedaan Nilai PDW, MPV, dan Jumlah Trombosit Pada Pre Dan Post Hemodialisa Pasien Gagal Ginjal Kronik. Jurnal Analis Kesehatan 7(1).

Widyastuti, R. (2014). Korelasi Lama Menjalani Hemodialisis dengan Indeks Massa Tubuh Pasien Gagal Ginjal Kronik di RSUD Arifin Achmad Provinsi Riau. Jurnal Gizi 1(2). 